\title{
Description of The Event of Anemia in Women of Real Age of Coral Cadets in Ciseeng, Bogor City 2021
}

\author{
${ }^{1}$ Hamidah Amani Fitri, ${ }^{2}$ Irawati Wulandari, ${ }^{3}$ Lubna Nabilla, ${ }^{4}$ Nada Udzrotu Shauma, ${ }^{5}$ Munaya \\ Fauziah
}

Faculty of Public Health, Muhammadiyah University of Jakarta

K.H. Ahmad Dahlan St, Cireundeu, Ciputat, South Jakarta, 15419

Email: nadaudzrotushauma@gmail.com

\begin{abstract}
Nutrition is one of the determining factors to achieve excellent and optimal health. Anemia is still a nutritional problem in the world, especially in developing countries, including Indonesia. Anemia is a condition in which a person's hemoglobin $(\mathrm{Hb})$ level in the blood is lower than normal. Infertile women are one of the groups at risk for anemia. Several research results in several regions in Indonesia show that the prevalence of anemia infertile women is still high. We aim to describe the incidence of anemia in women of childbearing age in Ciseeng, Bogor, 2021. Using a qualitative study design, employing FGD, in-depth interviews, and active observation. All informants suffer from moderate anemia with $\mathrm{Hb}$ levels between $8.7 \mathrm{~g} / \mathrm{dl}$ to $10.8 \mathrm{~g} / \mathrm{dl}$ and have several symptoms or signs of anemia, namely $5 \mathrm{~L}$, dizziness, fatigue, pale nails, lips, and eyelids. The lack of iron-containing foods and the presence of tea in the breakfast menu of the informants is one of the factors that make the informants suffer from anemia, due to the disruption of iron absorption by the tannins contained in tea. Most of the informants have abnormal menstrual patterns and this is one of the determinants of the incidence of anemia experienced by the informants. An overview of matters relating to the incidence of anemia in women of childbearing age at youth organizations in Ciseeng Bogor, including a description of nutrient intake, breakfast behavior, tea/coffee drinking behavior, menstruation, nutritional knowledge. All key informants had Hb levels below $12 \mathrm{~g} / \mathrm{dl}$, ie $8.7-10.8 \mathrm{~g} / \mathrm{dl}$. Three informants had $\mathrm{Hb}$ levels below $10 \mathrm{~g} / \mathrm{dl}, 12$ others had $\mathrm{Hb}$ levels $10-11 \mathrm{~g} / \mathrm{dl}$. The results of this $\mathrm{Hb}$ examination indicate that all informants suffer from anemia which is classified as moderate anemia according to the classification of anemia according to WHO.
\end{abstract}

Keywords: Anemia, Fertile women, Nutritional status 


\section{INTRODUCTION}

Anemia is one of the global health problems, especially in developing countries, which is estimated to reach $30 \%$. Anemia is common in the community, especially in adolescents and pregnant women. Adolescent girls are more prone to anemia, the monthly menstrual cycle is one of the causes. Iron deficiency is prone to occur in adolescent girls due to the increased need for iron during growth. In women of childbearing age, nutritional anemia is associated with poor reproductive function, a high proportion of maternal deaths (10-20\% of total deaths), an increased incidence of LBW (baby weight $<2.5 \mathrm{~kg}$ at birth), and intrauterine malnutrition (Ministry of Republic of Indonesia Health, 2017) (Wijayanti and Fitriani, 2019)

Nutrition is one of the determining factors to achieve excellent and optimal health. Anemia is still a nutritional problem in the world, especially in developing countries, including Indonesia. Anemia is a condition in which a person's hemoglobin $(\mathrm{Hb})$ level in the blood is lower than normal. Infertile women are one of the groups at risk for anemia. Several research results in several regions in Indonesia show that the prevalence of anemia infertile women is still high (SYARAH, Destriatania, and Febry, 2017).

Anemia can cause various health problems in adolescents. Adolescent girls who experience anemia have an impact on reproductive health status. Adolescence is a time that requires more nutrients. The high prevalence of anemia in adolescents is not followed by adolescent knowledge about the dangers of anemia. Nuniek's (2015) research results show that most young women do not know about anemia in adolescents. (Yusuf Sukman, 2017)

Based on this explanation, this study aims to describe the incidence of anemia in women of childbearing age in Ciseeng, Bogor, 2021

\section{METHODS}

This research was conducted using a qualitative method, which is a type of formative research that specifically provides techniques to obtain answers or in-depth information about a person's opinions and feelings. This research allows us to gain insight into the attitudes, beliefs, motivations, and behavior of the target population. Besides using qualitative methods, this research is also supported by quantitative data for variables of nutritional status and nutrient intake.

This research was conducted at the Ciseeng Youth Organization, Bogor City in 2021. The factors that will be studied are knowledge, attitudes, and family influences. This research activity was carried out in March - July 2021.

Sources of information or informants in this study were the closest people who were teenagers according to the research criteria. For the selection of informants by selecting certain samples are assessed according to the objectives or problems in the study and with the consideration 
that they are currently the most knowledgeable about the problems to be studied. The informants who will be conducting in-depth interviews are 4 young female informants from Karang Taruna. Informants were selected based on their capacity to explain the objectives of this study.

Table 1. List of Informant Data

\begin{tabular}{lccc}
\hline $\begin{array}{l}\text { Informant's } \\
\text { Initials }\end{array}$ & Age & Gender & Profession \\
\hline NUS & 21 & $\mathrm{P}$ & student \\
VA & 29 & $\mathrm{P}$ & Lawyer \\
SEI & 20 & $\mathrm{P}$ & Employee \\
NS & 21 & $\mathrm{P}$ & Student \\
\hline
\end{tabular}

There are two types of data sources used in this study, namely:

a. Primary data

Primary data were obtained from direct observations in the field with questions using previously prepared guidelines.

b. Secondary Data

Secondary data were obtained from journals related to this research as well as regulations related to this research.

The qualitative approach uses a small number of samples, therefore it is necessary to check the validity of the data, in qualitative research using triangulation, namely:

1. Source triangulation using facts from women of childbearing age (WUS) who became informants.

2. Triangulation method using three methods, namely in-depth interviews, FGD, and observation.

The purpose of data validation using various sources of informants and methods is expected to get a precise, accurate, and reliable analysis analysis

The research method used is a qualitative method using FGD, in-depth interviews, and active observation. Besides using qualitative methods, this research is also supported by quantitative data to describe the nutritional status and nutrient intake of the informants. The informants in the study consisted of the main informants, namely women of childbearing age, totaling 4 people in the Ciseeng area of Bogor city 2021.

\section{RESULTS AND DISCUSSIONS}

Table 2. Results of Interview Data Analysis

\begin{tabular}{|c|c|c|c|c|c|c|}
\hline No & Topic (question) & Meaning units & Code & Sub-category & Category & Theme \\
\hline & $\begin{array}{l}\text { Since when do you } \\
\text { suffer } \\
\text { anemia? }\end{array}$ & $\begin{array}{l}3 \text { junior high } \\
\text { school } \\
1 \text { high school } \\
2 \text { junior high }\end{array}$ & Mature & Mature & $\begin{array}{l}\text { History of suffering } \\
\text { from anemia }\end{array}$ & $\begin{array}{l}\text { Overview of the } \\
\text { incidence of } \\
\text { nutritional anemia } \\
\text { in women of }\end{array}$ \\
\hline
\end{tabular}




\begin{tabular}{|c|c|c|c|c|c|c|}
\hline No & Topic (question) & Meaning units & Code & Sub-category & Category & Theme \\
\hline & & $\begin{array}{l}\text { school } \\
2 \text { high school }\end{array}$ & & & & childbearing age \\
\hline & At what age? & $\begin{array}{l}15 \text { years } \\
16 \text { years } \\
14 \text { years } \\
17 \text { years }\end{array}$ & Mature & Mature & $\begin{array}{l}\text { Natural history of the } \\
\text { disease }\end{array}$ & \\
\hline & $\begin{array}{l}\text { The first time you } \\
\text { know whether } \\
\text { anemia is severe or } \\
\text { still mild? }\end{array}$ & $\begin{array}{l}\text { It's been bad } \\
\text { It's been bad } \\
\text { Still light } \\
\text { Still light }\end{array}$ & $\begin{array}{l}\text { Critical } \\
\text { Light }\end{array}$ & $\begin{array}{l}\text { Critical } \\
\text { Light }\end{array}$ & $\begin{array}{l}\text { Natural history of the } \\
\text { disease }\end{array}$ & \\
\hline & $\begin{array}{l}\text { How did you feel } \\
\text { when you first } \\
\text { found out about } \\
\text { anemia? }\end{array}$ & $\begin{array}{l}\text { Worry, sad } \\
\text { because blood HB } \\
\text { is low and must } \\
\text { be in blood } \\
\text { transfusion } \\
\text { Ordinary } \\
\text { Ordinary } \\
\text { Sad }\end{array}$ & $\begin{array}{l}\text { Worry } \\
\text { Sad } \\
\text { Ordinary }\end{array}$ & $\begin{array}{l}\text { Worry } \\
\text { Sad } \\
\text { Ordinary }\end{array}$ & $\begin{array}{l}\text { Natural history of the } \\
\text { disease }\end{array}$ & \\
\hline & $\begin{array}{l}\text { What do you think } \\
\text { the signs are from } \\
\text { how you feel? }\end{array}$ & $\begin{array}{l}\text { Dizziness, } \\
\text { weakness, } \\
\text { lethargy } \\
\text { Fainting, tired } \\
\text { Dizzy, weak } \\
\text { Tired, tired } \\
\end{array}$ & $\begin{array}{l}\text { Dizzy } \\
\text { Weak } \\
\text { Sluggish } \\
\text { Faint } \\
\text { Fatigue } \\
\text { Weak } \\
\end{array}$ & $\begin{array}{l}\text { Dizzy } \\
\text { Weak } \\
\text { Sluggish } \\
\text { Faint } \\
\text { Fatigue } \\
\text { Weak } \\
\end{array}$ & $\begin{array}{l}\text { Natural history of the } \\
\text { disease }\end{array}$ & \\
\hline & $\begin{array}{l}\text { How did you feel } \\
\text { physically the first } \\
\text { time? }\end{array}$ & $\begin{array}{l}\text { Pale, lethargic } \\
\text { Achy, tired and } \\
\text { tired } \\
\text { Firefly eyes } \\
\text { Pale eyelids and } \\
\text { lips, }\end{array}$ & $\begin{array}{l}\text { Pale, } \\
\text { lethargic } \\
\text { Achy, tired } \\
\text { and tired } \\
\text { Firefly eyes } \\
\text { Pale eyelids } \\
\text { and lips } \\
\end{array}$ & $\begin{array}{l}\text { Pale, lethargic } \\
\text { Achy, tired and tired } \\
\text { Firefly eyes } \\
\text { Pale eyelids and lips, }\end{array}$ & $\begin{array}{l}\text { Natural history of the } \\
\text { disease }\end{array}$ & \\
\hline & $\begin{array}{l}\text { Please tell me first, } \\
\text { have you ever } \\
\text { thought that you } \\
\text { might get this } \\
\text { disease? }\end{array}$ & $\begin{array}{l}\text { No, because } \\
\text { respondents like } \\
\text { to eat animals } \\
\text { Yes, because } \\
\text { parents are } \\
\text { anemic } \\
\text { Ever, because I } \\
\text { often feel the } \\
\text { signs } \\
\text { Unthinkable }\end{array}$ & $\begin{array}{l}\text { Unthinkable } \\
\text { Yes, I } \\
\text { thought about } \\
\text { it } \\
\text { He thought } \\
\text { Unthinkable }\end{array}$ & $\begin{array}{l}\text { Unthinkable } \\
\text { Yes, I thought about it } \\
\text { He thought } \\
\text { Unthinkable }\end{array}$ & $\begin{array}{l}\text { Natural history of the } \\
\text { disease }\end{array}$ & \\
\hline & $\begin{array}{l}\text { Who } \\
\text { advised/conveyed } \\
\text { about the existence } \\
\text { of this disease } \\
\text { when he was } \\
\text { healthy? }\end{array}$ & $\begin{array}{l}\text { Parent } \\
\text { Parent } \\
\text { Parent } \\
\text { Friend } \quad \text { who } \\
\text { advises }\end{array}$ & $\begin{array}{l}\text { Parent } \\
\text { Friend }\end{array}$ & $\begin{array}{l}\text { Parent } \\
\text { Friend }\end{array}$ & $\begin{array}{l}\text { Natural history of the } \\
\text { disease }\end{array}$ & \\
\hline & $\begin{array}{l}\text { Please tell me when } \\
\text { you found out that } \\
\text { you had anemia, } \\
\text { did you go for } \\
\text { treatment? }\end{array}$ & $\begin{array}{l}\text { To the hospital } \\
\text { Clinic } \\
\text { Clinic } \\
\text { Clinic }\end{array}$ & $\begin{array}{l}\text { House sick } \\
\text { Clinic }\end{array}$ & $\begin{array}{l}\text { House sick } \\
\text { Clinic }\end{array}$ & $\begin{array}{l}\text { Natural history of the } \\
\text { disease }\end{array}$ & \\
\hline & $\begin{array}{l}\text { (If yes.... why } \\
\text { treatment?/If } \\
\text { no.... why not }\end{array}$ & $\begin{array}{l}\mathrm{Hb} \text { levels are } \\
\text { already low } \\
\text { Due to fainting }\end{array}$ & $\begin{array}{l}\text { Hb low } \\
\text { Faint } \\
\text { Typhoid }\end{array}$ & $\begin{array}{l}\text { Hb low } \\
\text { Faint } \\
\text { Typhoid }\end{array}$ & Treatment behavior & \\
\hline
\end{tabular}




\begin{tabular}{|c|c|c|c|c|c|c|}
\hline No & Topic (question) & Meaning units & Code & Sub-category & Category & Theme \\
\hline & $\begin{array}{l}\text { treatment?) Where } \\
\text { to go for treatment? }\end{array}$ & $\begin{array}{l}\text { Because I have } \\
\text { typhoid } \\
\text { Due to a medical } \\
\text { check-up }\end{array}$ & $\begin{array}{l}\text { Medical } \\
\text { check-up }\end{array}$ & Medical check-up & & \\
\hline
\end{tabular}
check-up

$\begin{array}{lllll}\text { Do you regularly } & \text { Not } & & & \\ \text { take Fe tablets or } & \text { Not } & & & \text { Treatment behavior } \\ \text { blood-boosting } & \text { Not } & \text { Not } & \text { Not } & \\ \text { tablets during } & \text { Not } & & \end{array}$
menstruation?

$\begin{array}{lllll}\begin{array}{l}\text { Is your menstrual } \\ \text { cycle regular every } \\ \text { month? }\end{array} & \begin{array}{l}\text { Irregular } \\ \text { Irregular } \\ \text { Regular } \\ \text { Regular }\end{array} & \text { Irregular } & \text { Irregular } & \text { Menstrual cycle } \\ \begin{array}{l}\text { If not, how many } \\ \text { days per month? }\end{array} & \begin{array}{l}3 \text { months bleeding } \\ 1 \text { month without } \\ \text { menstruation }\end{array} & \begin{array}{l}\text { Not regular } \\ \text { Regular }\end{array} & \begin{array}{l}\text { Not regular } \\ \text { Regular }\end{array} & \text { Menstrual cycle } \\ \end{array}$

\begin{tabular}{lllll}
$\begin{array}{l}\text { Did you finish the } \\
\text { blood boost tablet } \\
\text { that was given? }\end{array}$ & $\begin{array}{l}\text { Not spent } \\
\text { Not consuming } \\
\text { Not spent }\end{array}$ & Not spent Not spent & Treatment behavior \\
& & & \\
\hline
\end{tabular}

\begin{tabular}{|c|c|c|c|c|}
\hline $\begin{array}{l}\text { Do you have a } \\
\text { family who suffers } \\
\text { from anemia? }\end{array}$ & $\begin{array}{l}\text { Yes, here } \\
\text { Yes, here } \\
\text { There is not any } \\
\text { There is not any }\end{array}$ & $\begin{array}{l}\text { Exist, family, } \\
\text { There is not } \\
\text { any } \\
\text { family }\end{array}$ & $\begin{array}{l}\text { Exist, family, } \\
\text { There is not any } \\
\text { family }\end{array}$ & genetic \\
\hline
\end{tabular}

Tell me how your Often do activities daily activities before, then not were before you after

found out you were It's the same sick and after you before and after found out, tell me getting sick the difference? Or It's the same is it the same? before and after Which one is more frequent and what activities do you do? getting sick Previously, he often did activities, then after he was exposed to the disease his activities were reduced

What are the bad Anxious because habits that are often of low HB blood done by siblings Yes, I panic that have a bad because I often impact on anemia? faint

Yes, worry is less staying up late Anxiety, take care of yourself more Doing bad habits Doing activities

Doing activities Not doing Not doing activities Physical activity by reducing strenuous activities and maintaining a healthy diet activities 


\begin{tabular}{llllll}
\hline No & Topic (question) & \multicolumn{1}{c}{ Meaning units } & Code & Sub-category & Category \\
\hline your diet before & not having & changes & Not To do the dietary & \\
you found out you & breakfast, and Not To do the habit \\
were sick and after & irregular eating dietary habit & \\
you found out? Tell patterns & & \\
me about the & Staying up late \\
changes? Do you and irregular & \\
like to eat food eating patterns & \\
sourced from Staying up late & \\
animals? & and irregular \\
& eating patterns \\
& Staying up late \\
& and too much \\
\end{tabular}

$\begin{array}{lllll}\text { Do you like to } & \text { Often } & \text { Like } & \text { Like } \\ \text { drink tea with } & \text { Like } & \text { Do not like } & \text { Do not like } & \text { Dietary habit } \\ \text { meals? } & & \text { Often } & \text { Dike }\end{array}$

Do not like

Tell me how Anxious because anxious and of low HB blood worried after Yes, I panic knowing about because I often anemia? How about faint family? What is his Yes, worry is less hope?

staying up late
Anxiety, take care

of yourself more

by reducing

strenuous

activities and

maintaining a

healthy diet

Do you often share Yes, the

stories with your

parents or friends

who are also

anemic?

respondent's sister

has anemia and

supports each other

Yes, tell your

friends and

parents

Yes, I told my

parents

Yes tell a friend

Please tell me how Yes, I feel happy

he felt after because this

knowing there was disease is easy to

a treatment for get treatment anemia?

Yes happy

because the

Worried Worried

Panic Panic

Share a story

Often Often $\quad$ Share a story

Feeling

happy

Feeling happy

Respondent's

feelings
Tell me how your religion or belief teaches you to live healthily and deal with illness? disease has a cure

Yes feeling happy

Yes very happy

Patience,

endeavor, pray

Allah always

teaches patience

Be patient

Effort sincerity,

belief because all 


\begin{tabular}{|c|c|c|c|c|c|c|}
\hline No & Topic (question) & Meaning units & Code & Sub-category & Category & Theme \\
\hline & & $\begin{array}{l}\text { diseases have a } \\
\text { cure } \\
\text { Pray, be patient, } \\
\text { and improve a } \\
\text { healthy diet } \\
\text { Don't overeat, } \\
\text { stop eating before } \\
\text { you're full, set a } \\
\text { good diet }\end{array}$ & & & & \\
\hline & $\begin{array}{l}\text { What is your advice } \\
\text { to those who are } \\
\text { still healthy so they } \\
\text { don't get anemia? }\end{array}$ & $\begin{array}{l}\text { You must } \\
\text { maintain a healthy } \\
\text { diet, balanced } \\
\text { nutrition, exercise } \\
\text { regularly, take } \\
\text { blood-boosting } \\
\text { tablets regularly, } \\
\text { don't stay up late, } \\
\text { get enough rest } \\
\text { Take care of your } \\
\text { body before you } \\
\text { get anemia, let } \\
\text { alone your diet } \\
\text { Maintain a } \\
\text { healthy diet, eat } \\
\text { healthy food, and } \\
\text { don't stay up late } \\
\text { Take care of your } \\
\text { health, love } \\
\text { yourself and your } \\
\text { body because } \\
\text { health is valuable }\end{array}$ & $\begin{array}{l}\text { Keep the diet } \\
\text { Balanced } \\
\text { nutrition } \\
\text { Sport } \\
\text { Take } \\
\text { medication } \\
\text { regularly } \\
\text { Don't sleep } \\
\text { too late } \\
\text { Keep well }\end{array}$ & $\begin{array}{l}\text { Keep the diet } \\
\text { Balanced nutrition } \\
\text { Sport } \\
\text { Take medication } \\
\text { regularly } \\
\text { Don't sleep too late } \\
\text { Keep well }\end{array}$ & $\begin{array}{l}\text { Respondent's } \\
\text { suggestion }\end{array}$ & \\
\hline
\end{tabular}

All informants suffered from moderate anemia with $\mathrm{Hb}$ levels between $8.7 \mathrm{~g} / \mathrm{dl}$ to $10.8 \mathrm{~g} / \mathrm{dl}$ and had several symptoms or signs of anemia, namely $5 \mathrm{~L}$, dizziness, tiredness, pale nails, lips, and eyelids. The lack of foods containing iron and the presence of tea in the breakfast menu of the informants are one of the factors that make the informants suffer from anemia, due to the disruption of the absorption of iron by the tannins contained in tea. Most of the informants have abnormal menstrual patterns and this is one of the determinants of the incidence of anemia experienced by the informants

Table 3. Hb levels infertile women, youth organizations

\begin{tabular}{lcc}
\hline No & Respondent's name & Hb level $(\mathbf{g r} / \mathbf{d l})$ \\
\hline 1. & Nus & $9 \mathrm{gr} / \mathrm{dl}$ \\
2. & Va & $10 \mathrm{gr} / \mathrm{dl}$ \\
3. & Sei & $11 \mathrm{gr} / \mathrm{dl}$ \\
4. & Ns & $10 \mathrm{gr} / \mathrm{dl}$ \\
\hline
\end{tabular}

Overview of the Incidence of Anemia in Infertile Women in Youth Organizations (Bakta, 2009) in (Apriani, 2014) states that anemia is caused by a decrease in the production of red blood cells 
and hemoglobin, an increase in the destruction of red cells (hemolysis), or blood loss due to heavy bleeding. Anemia is defined as a condition in which the $\mathrm{Hb}$ value in the blood is lower than normal. All informants had $\mathrm{Hb}$ levels below $12 \mathrm{~g} / \mathrm{dl}$, ie $9 \mathrm{gr} / \mathrm{dl}-11 \mathrm{gr} / \mathrm{dl}$. Two informants had Hb levels below $11 \mathrm{~g} / \mathrm{dl}, 1$ person had $\mathrm{Hb}$ levels $10 \mathrm{gr} / \mathrm{dl}$, and 1 person had $\mathrm{Hb}$ levels $9 \mathrm{gr} / \mathrm{dl}$. The results of the $\mathrm{Hb}$ examination showed that all informants suffered from anemia which was classified as moderate anemia according to the classification.

Anemia is the most common nutritional problem in the productive age group. About a third of adolescents and WUS suffer from iron deficiency anemia and continue during pregnancy. Iron nutritional anemia is found in $40 \%$ of pregnant women. Chronic Energy Deficiency (KEK) is found in women aged 15-49 years, which is characterized by the proportion of LILA $<23.5 \mathrm{~cm}$, by $24.9 \%$ in 1999 and decreasing to $16.7 \%$ in 2003. In general, the proportion of WUS with risk SEZ is quite high at young ages (15-19 years), and decreases in the older age group, this condition is concerning considering that WUS with the risk of SEZ tend to give birth to LBW babies which will eventually inhibit growth in children under five.

Signs of nutritional anemia begin with depletion of iron stores (ferritin) and increased iron absorption which is described by increased iron-binding capacity. At a more advanced stage in the form of depletion of iron stores, reduced transferrin saturation reduced amount of protoporphyrin converted to heme and will be followed by a decrease in serum ferritin levels. Finally, anemia occurs with a characteristic of low $\mathrm{Hb}$ levels. Symptoms that are often experienced include lethargy, weakness, dizziness, dizzy eyes, and a pale face. Anemia can cause various impacts on adolescents, including lowering the body's resistance so that it is susceptible to disease, decreased activity. ( et al., 2018)

This study includes a description of the incidence of anemia in women of childbearing age at Ciseeng, Bogor City, an overview of matters relating to the incidence of anemia in women of childbearing age. An overview of matters relating to the incidence of anemia in women of childbearing age at Karang Taruna in Ciseeng Bogor, including a description of nutrient intake, breakfast behavior, tea/coffee drinking behavior, menstruation, nutritional knowledge.

Breakfast is activity is important to eat and drink before doing physical activity in the morning until noon, breakfast also serves to get a source of energy and nutrients so that you can think. Breakfast is the first menu for a person to eat by meeting $15-30 \%$ of the daily nutritional needs to live a healthy, active, and intelligent life.

According to Khomsan (2002), breakfast can contribute 25 percent of the energy contribution of the number of needs nutrition days. Breakfast is needed to fill the stomach that has been empty for 8-10 hours so that the glucose levels that originally fell will increase again. the proportion of macronutrients recommended for school children during the day according to the general guidelines 
for balanced nutrition (PUGS) includes carbohydrates $50-60 \%$. Fat is about $25 \%$ and protein is about $15 \%$, this proportion includes breakfast. Breakfast contributes energy about $25 \%$ of the daily nutritional needs with a significant amount.(SYARAH, Destriatania and Febry, 2017)

All the main informants have described the informant's breakfast behavior, the information includes how often the informant has breakfast, the time, and the food eaten at breakfast. All informants are used to having breakfast every day, and most of them have breakfast before leaving for activities, Nus has breakfast around eight, Va and Nus have breakfast at six in the morning, but only sometimes, if you don't have breakfast at six, then you have breakfast around ten, the same as Sei having breakfast when feeling hungry. the food eaten by VA at breakfast is usually rice with eggs, instant noodles, fried rice.

Menstruation is periodic and cyclic bleeding from the uterus which is characterized by the shedding of the endometrium. Menstrual patterns can be measured based on three things, namely the menstrual cycle, the length of menstruation, and the number of menstrual cyclesbloodduring menstruation. The menstrual cycle is the distance between the first menstrual period and the next first menstruation. The duration of menstruation is the first menstruation until menstruation stops. The amount of blood is the amount of blood that comes out of the first menstruation until it stops.

Normal menstruation involves the maturity of the neuroendocrine system. If one step in the system is disturbed, then menarche and menstrual cycles can be absent or irregular. According to Manuaba (2009), the division of menstrual cycle disorders is oligomenorrhea, oligomenorrhea, and amenorrhea. Polymenorrhea is menstruation with a cycle of fewer than 21 days. Oligomenorrhea is a menstrual cycle that exceeds 35 days. Disorders of the menstrual process such as the length of the menstrual cycle can cause chronic disease. The concept of menstrual disorders, in general, is a disorder of menstrual bleeding patterns or seen from the cycle. These disorders can pose a pathological risk if associated with excessive blood loss, interfere with daily activities, an indication of incompatible ovaries at the time of conception, or signs of cancer. According to research (Proverawati, 2009), menstrual cycle disorders caused by stress will disrupt the systemmetabolismso easily tired, weight loss drastically, even sickly. When the metabolism is disturbed, the menstrual cycle is also disturbed. (Yusuf Sukman, 2017)

From the information to get an overview of the informant's menstrual pattern, this study includes information about the length of the menstrual period and the length of the day when a lot of blood comes out. The menstrual day length of seven informants varied widely, ranging from four to ten days. nf and sei answered regularly. And Nus had the longest menstrual period, which was seven to ten days and once up to 3 months. For VA sometimes not menstruating.

According to the results of research by Albery (2011), family support is a necessary factor to shape the intentions of young women in consuming blood-added tablets to prevent anemia. With the 
high support given by the family, a normative belief will be formed and young women will tend to form a positive perception of the consumption of blood-added tablets, to form a strong intention to take blood-added tablets to avoid the risk of anemia. Therefore, the formation of a strong intention of young women in consuming blood-added tablets requires social influence and support from the family.

(WHO 2005) stated that the Government launched a program to provide iron supplements or blood-added tablets (TTD) for young women to contribute to breaking the intergenerational cycle of malnutrition. The government stated that the administration of TTD with a composition consisting of $60 \mathrm{mg}$ of elemental iron (in the form of ferrous sulfate, ferrous gluconate) and $0.400 \mathrm{mg}$ of folic acid in adolescent girls aged 12-18 years and women of childbearing age (WUS).

Iron is needed for the formation of blood and is also needed by various enzymes, it is also needed to transport electro (cytochromes), to activate oxygen, so that when iron levels are low, nothing binds to hemoglobin in the blood and there is a reduction in Hb levels in the blood, which is called anemia. . Iron given orally is one way to prevent and control anemia given to adolescent girls as much as 1 tablet/week and 1 tablet/day for 10 days during menstruation (Kemenkes, 2016). (Irianti and Sahiroh, 2019)

From information Nus, Va, Sei, Ns know that the tablets add blood to increase blood, prevent, and treat anemia. Nus, Va, Sei, and Ns took blood-boosting tablets. Nus and Va take blood-added tablets when they feel weak, Sei doesn't regularly take blood-added tablets, and Ns regularly takes blood-added tablets. Excerpts from each of the informants' answers.

According to research Besral, et al 2007) The habit of drinking tea has become a culture for the world's population. Besides water, tea is the most consumed beverage by humans. The average tea consumption of the world's population is $120 \mathrm{ml} /$ day per capita. Tea can inhibit the absorption of nonheme iron (a substance derived from vegetables) by $79-94 \%$ if taken together. In addition, in tea, there are compounds called tannins. These tannins can bind to several metals such as iron, calcium, and aluminum, then form chemically complex bonds. Because in a continuously bound position, the iron and calcium compounds found in food are difficult to absorb by the body, causing a decrease in iron $(\mathrm{Fe})$.

The causes of iron nutritional anemia are lack of iron intake, reduced iron supplies in food, increased iron requirements, chronic blood loss, malaria, hookworms, other infections, lack of knowledge about iron anemia, and poor eating habits. accompanied by tea. (v. M. buyanov, 1967)

From the interviews, most of the informants stated that they had the habit of drinking tea after eating. Nus, Va, and Sei like to drink tea after eating, while Ns doesn't like drinking tea after eating

The researcher did not include the nutritional knowledge variable because to obtain information about nutritional knowledge researcher must first ask the informant's nutritional intake, 
while the researcher does not ask about the informant's nutritional intake. Researchers only use primary data to determine the Hb level of all informants. The informants' answers during FGDs and interviews depended on the situation and circumstances around them.

In the perspective of Islam, Health in Islam is an important matter, it is a great blessing that every service should be grateful for.

Ibnul Jauzi said that sometimes a person has a healthy body, but he does not have free time because he is busy with his livelihood. Sometimes a person has free time but his body is not healthy. If these two blessings (free time and a healthy body) are owned by someone, then laziness dominates him to do obedience to Allah; then he is the one who is deceived. (Fathul Bari bi Syarhi Sahihil Bukhari: 14/184). In the respondents we studied, they were all obedient in worship and were trying and patient for the healing of the disease they were suffering from, therefore they believed that Allah SWT would give them healing.

\section{CONCLUSIONS AND SUGGESTIONS}

\section{Conclusions}

1. This study includes a description of the incidence of anemia in women of childbearing age at Ciseeng, Bogor City, an overview of matters relating to the incidence of anemia in women of childbearing age. An overview of matters relating to the incidence of anemia in women of childbearing age at Karang Taruna in Ciseeng Bogor, including a description of nutrient intake, breakfast behavior, tea/coffee drinking behavior, menstruation, nutritional knowledge.

2. All key informants had $\mathrm{Hb}$ levels below $12 \mathrm{~g} / \mathrm{dl}$, ie $8.7-10.8 \mathrm{~g} / \mathrm{dl}$. Three informants had $\mathrm{Hb}$ levels below $10 \mathrm{~g} / \mathrm{dl}, 12$ others had Hb levels 10-11 g/dl. The results of the $\mathrm{Hb}$ examination showed that all informants suffered from anemia classified as moderate anemia according to the WHO classification of anemia.

3. All the main informants have described the informant's breakfast behavior, the information includes how often the informant has breakfast, the time, and the food eaten at breakfast. All respondents are used to having breakfast every day, and most of them have breakfast before leaving for activities.

4. From the information to get a picture of the menstrual pattern, the respondents of this study included information about the length of the menstrual period and the length of the day when a lot of blood came out. The length of the menstrual period of the seven informants varied widely, from four to ten days.

5. From some of the information obtained regarding the symptoms of anemia vary widely, the respondents answered quite a lot, including dizziness when standing after squatting, drowsiness, weakness, lack of enthusiasm, and always feeling like sleeping. 
6. From the respondent's information, they know that tablets add blood to add blood, prevent, and treat anemia, take tablets to add blood.

7. Most of the main informants had prior knowledge of anemia, had irregular eating patterns, and did not eat food sourced from animals.

8. From the interviews, most of the informants stated that they had the habit of drinking tea after eating.

\section{Suggestions}

1. It is better than related agencies such as the education office, health office, health center, and local youth organizations to further improve nutrition and health education, which is integrated into subjects such as science (Biology) and Physical Education (Physical Education and Health).

2. It's better to improve it even more for the youth community through youth cadres, it can be used as a means to provide counseling about anemia to young women, especially youth organizations.

3. To anticipate the insufficient intake of nutrients in youth groups, especially young women, communication between the administrators and parents of young women should be carried out so that they pay attention to the food, nutritional status, and health of their children.

4. The youth organizations should pay more attention to, foster, and direct the quality of food sold in the local area, to achieve the fulfillment of nutrient intake for youth organizations, especially fertile women.

\section{REFERENCES}

1. Irianti, S., and Sahiroh (2019) Overview Factors Of Consumption Of Blood Added Tablets In Female Overview Factors Of Consumption Of Blood Added Tablets In Female

2. Adolescent', Oxytocin: Scientific Journal of Midwifery, 6(2), pp. 92-97.

3. v. M. buyanov (1967) '済 無No Title No Title No Title', Angewandte Chemie International Edition, 6(11), 951-952., pp. 167-171.

4. SYARAH, A., Destriatania, S. and Febry, F. (2017) 'Factors of Breakfast Habits in Young Women in Junior High Schools in Palembang City. Available at:

5. https://repository.unsri.ac.id/12642/2/RAMA_ 13201

6. _10011181320013_0031128601_0008027801_01_front_ref.pdf.

7. Wijayanti, E. and Fitriani, U. (2019) 'Profile of Nutrient Consumption in Anemia of Childhood Age', Indonesian Micro Nutrition Media, 11(1), pp. 39-48. doi:10.22435/mgmi.v11i1.2166.

8. Yusuf Sukman, J. (2017) 'Опыт аудита обеспечения ачества езопасности едицинской еятельности едицинской организации о азделу «Эпидеологичеа'ая, еза 4аая, езадзаая, езадзастникая, еза 4 огичегича оегича огичестьа огичестьа огичестьа огичестьа 
огичестьа огичестьа огичеза, Yusufeзо о Yusufoгича, Yusuf Sukman, J. Yusuf Sukman, J. Yusuf Sukman, J., Yusuf Sukman, J. 9-15.

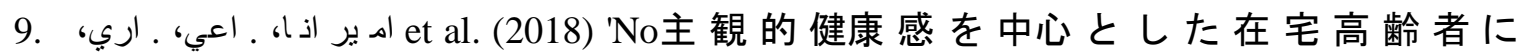
おける健康関連指標に関する共分散構造 分析Title', Biomass Chem Eng, 3(2), p. Available at: http://journal.stainkudus.ac.id/index.php/equilibrium/article/view/1268/1127\%0Ahttp://public acoes.cardiol.br/portal/ijcs/portugues/2018/v3103/pdf 3103009.pdf\%0Ahttp://www.scielo.org.co/scielo.php?script=sci_arttext\&pid=S0121$75772018000200067 \& \operatorname{lng}=$ en\&tlng=.

10. Irianti, S., and Sahiroh (2019) 'Overview Factors of Blood Added Tablets In Female Adolescent Consumption Factors Overview Factors Of Blood Added Tablets In Female Adolescent', Oxytocin: Scientific Journal of Midwifery, 6(2), pp. 92-97.

11. v. M. buyanov (1967) '済 無No Title No Title No Title', Angewandte Chemie International Edition, 6(11), 951-952., pp. 167-171.

12. SYARAH, A., Destriatania, S. and Febry, F. (2017) 'Factors of Breakfast Habits in Young Women in Junior High Schools in Palembang City. Available at: https://repository.unsri.ac.id/12642/2/RAMA_ _10011181320013_0031128601_0008027801_01_front_ref.pdf.

13. Wijayanti, E. and Fitriani, U. (2019) 'Profile of Nutrient Consumption in Anemia of Childhood Age', Indonesian Micro Nutrition Media, 11(1), pp. 39-48. doi:10.22435/mgmi.v11i1.2166.

14. Yusuf Sukman, J. (2017) 'Опыт аудита обеспечения ачества езопасности едицинской еятельности едицинской организации о азделу «Эпидеологичеа'ая, еза 4аая, езадзаая, езадзастникая, еза 4 огичегича оегича огичестьа огичестьа огичестьа огичестьа огичестьа огичестьа огичеза, Yusufeзо о Yusufoгича, Yusuf Sukman, J. Yusuf Sukman, J. Yusuf Sukman, J., Yusuf Sukman, J. 9-15.

15. et al. (2018) 'No主観 的健康感を中心 とした在宅高齢 者に おける健康関連 指標に関する共分散構造 分析Title', Biomass Chem Eng, 3(2), p.

Available

at:

http://journal.stainkudus.ac.id/index.php/equilibrium/article/view/1268/1127\%0Ahttp://public acoes.cardiol.br/portal/ijcs/portugues/2018/v3103/pdf /3103009.pdf\%0Ahttp://www.scielo.org.co/scielo.php?script=sci_arttext\&pid=S0121$75772018000200067 \& \operatorname{lng}=e n \& \operatorname{tng}=$. 
Volume I Tahun 2021

November 2021
E-ISSN: 2808-5361

http://e-journal.fkmumj.ac.id/
Proceeding The First Muhammadiyah InternasionalPublic Health and Medicine Conference 